\title{
Pelatihan Penyusunan Perangkat Perencanaan Pembelajaran Kepada Para Guru
}

\author{
Sulastri \\ aProgram Studi Pendidikan Pancasila dan Kewarganegaraan, Fakultas Keguruan dan Ilmu Pendidikan, \\ Universitas Pamulang* \\ lastrisulastri1990@gmail.com \\ *korespondensi penulis
}

Naskah diterima: 25 Februari 2019, direvisi: 10 Maret 2019, disetujui: 27 Maret 2019

\begin{abstract}
Abstrak
Dalam rangka melaksanakan proses pembelajaran yang sudah ditetapkan di dalam silabus, guru harus menyusun Rencana Pelaksanaan Pembelajaran (RPP). RPP merupakan pedoman bagi guru dalam melaksanakan pembelajaran baik di kelas, laboratorium, dan/atau lapangan untuk mencapai setiap kompetensi dasar. Oleh karena itu, apa yang tertuang di dalam RPP memuat hal-hal yang berkaitan langsung dengan kegiatan pembelajaran dalam upaya mencapai penguasaan dari setiap kompetensi dasar. Namun pada kenyataannya terdapat kesulitan dalam menyusun perangkat perencanaan pembelajaran yakni RPP, Prota, serta Prosem. Metode kegiatan yang digunakan adalah dengan cara pemberian materi umum, Tanya jawab, praktik, dan penugasan. Setelah diberikan pelatihan penyusunan perencanaan perangkat pembelajaran maka para dewan guru lebih memahami dan mampu mengembangkan perangkat pembelajaran dengan baik lagi. Peningkatan pemahaman guru dalam mengembangkan perangkat pembelajaran meningkat dari $50 \%$ menjadi 91,6 \%. Oleh karena itu, kegiatan pengabdian masyarakat yang diberikan dalam bentuk pelatihan tersebut memberikan pengalaman belajar yang bermanfaat sesuai kebutuhan guru serta para dosen pengabdi. Kegiatan pengabdian khususnya dalam memberikan pelatihan ini harus terus dilaksanakan guna membantu peningkatan skill para guru dalam mengembangkan perangkat pembelajaran.
\end{abstract}

Kata-kata kunci:pelatihan; penyusunan; perangkat perencanaan pembelajaran

Abstract
In order to implement the learning process that has been established in the syllabus, the
teacher must develop a Learning Implementation Plan (RPP). RPP is a handle for teachers in
carrying out learning both in class, laboratory, and / or field to achieve every basic
competency. Therefore, what is contained in the RPP contains matters that are directly related
to learning activities in an effort to achieve mastery of each of the Basic Competencies. But in
reality there are difficulties in arranging learning planning tools namely RPP, Prota, and
Prosem. The method of activity used is by survey. After being given training in the preparation
of learning device planning, the teacher councils are more understanding and able to develop
learning devices well again. Increased teacher understanding in developing learning devices
increasedfrom 50\% to $91.6 \%$. Therefore, the community service activities provided in the
form of training provide a useful learning experience according to the needs of the board of
teachers and dedicated lecturers. Dedication activities especially in providing this training
must continue to be carried out to help improve the skills of the teachers in developing
learning devices.
Key words: training; drafting; learning planning device




\section{PENDAHULUAN}

Dunia pendidikan terus berkembang seiring dengan perkembangan zaman, perkembangan ini mempunyai tujuan untuk meningkatkan mutu pendidikan khususnya di Indonesia. Oleh Karena itu pemerintah terus melakukan upaya peningkatan mutu pendidikan dengan dipertegas dalam UU No 20 Tahun 2003 pasal 4 ayat 4 menyatakan bahwa "pendidikan diselenggarakan dengan member keteladanan membangun keamanan dan mengembangkan kreativitas peserta didik dalam proses pembelajaran. Pendidikan nasional berfungsi megembangkan kemampuan membentuk watak serta peradaban bangsa yang bermartabat dalam rangka mencerdaskan kehidupan bangsa, bertujuan untuk berkembangnya potensi peserta didik agar menjadi manusia yang beriman dan bertakwa kepada Tuhan Yang Maha Esa, berakhlak mulia, sehat,berilmu, cakap, kreatif, mandiri, dan menjadi warga Negara yang demokratis serta bertanggung jawab".

Selain itu dalam Pasal 36 Ayat 1 UU No 20 Tahun 2003 menyatakan bahwa "Implementasi dari tujuan pendidikan tersebut, salah satunya ditentukan melalui pengembangan kurikulum berdasarkan standar nasional pendidikan dan berdasarkan prinsip diversifikasi sesuai dengan satuan pendidikan, potensi daerah, dan peserta didik".
Seiring dengan penjelasan Undangundang tersebut, perubahan penting yang telah terjadi dalam dunia pendidikan di Indonesia guna mencapai tujuan pendidikan salah satunya adalah perubahan kurikulum.

Kurikulum sendiri menurut undangundang No 20 tahun 2013 adalah seperangkat rencana dan pengaturan mengenai tujuan, isi/bahan pelajaran serta cara yang digunakan sebagai pedoman penyelenggaraan kegiatan pembelajaran untuk mencapai tujuan pendidikan tertentu.

Dari kurikulum sebelumnya yakni kurikulum 2006 berubah menjadi kurikulum 2013. Kurikulum 2013 disahkan dan mulai diberlakukan pada Juli 2013 tapi tidak secara langsung semua sekolah menerapkannya akan tetapi ada sekolah percontohan yang ditunjuk dari setiap daerah da setiap jenjangnya. Untuk tahun ini sebagian sekolah masih ada yang menggunakan kurikulum 2006 dan sebagian lagi menggunakan kurikulum 2013.

$$
\text { Kurikulum } 2013 \text { merupakan }
$$

kurikulum yang terintegrasi, maksud dari teritegrasi itu memadukan skill, theme, concept, dan topic.

$$
\text { Menurut E.Mulyasa, (2013: 7) }
$$

"Kurikulum 2013 lebih ditekankan pada pendidikan karakter, terutama pada tingkat dasar, yang akan menjadi pondasi bagi tingkat berikutnya. Melalui pengembangan 
kurikulum 2013 yang berbasis karakter dan kompetensi, kita berharap bangsa ini menjadi bangsa yang bermartabat, dan masyarakatnya memiliki nilai tambah (added value), dan nilai jual yang bisa ditawarkan kepada orang lain di dunia, sehingga kita bisa bersaing, bersanding dan bahkan bertanding dengan bangsa-bangsa lain dalam pencaturan global. Hal ini di mungkinkan jika implementasi kurikulum 2013 betul-betul dapat menghasilkan insan yang produktif, kreatif, inovatif, dan berkarakter".

Telah disadari bersama bahwa dengan adanya perubahan kurikulum maka sudah pasti diikuti perubahan system pengajarannya dan juga perangkat perencanaan pembelajaran yakni silabus dan Rencana Pelaksanaan Pembelajaran. Untuk mencapai keberhasilan penetapan kurikulum 2013 maka didukung oleh keberhasilan dari guru dalam menjalankan pengajaran di dalam kelas.

Suhadi (2007), mengemukakan bahwa perangkat pembelajaran adalah sejumlah bahan, alat, media, petunjuk dan pedoman yang digunakan dalam proses pembelajaran. Perangkat pembelajaran menjadi tolak ukur dalam pelaksanaan proses pembelajaran.

Dalam Permendikbud No. 65 Tahun 2013 tentang Standar Proses Pendidikan Dasar dan Menengah disebutkan bahwa penyusunan perangkat pembelajaran merupakan bagian dari perencanaan pembelajaran. Perencanaan pembelajaran dirancang dalam bentuk silabus dan RPP yang mengacu pada standar isi. Selain itu, dalam perencanaan pembelajaran juga dilakukan penyiapan media dan sumber belajar, perangkat penilaian, dan skenario pembelajaran.

Seorang guru harus mampu dalam merencanakan pembelajaran, melaksanakan proses pembelajaran yang bermutu, serta menilai dan mengevaluasi hasil pembelajaran. Pelaksanaan pembelajaran yang bermutu tentu terkait dengan kesiapan guru seperti pemilihan metode, ketersediaan media, dan kesiapan peserta didik. Guru yang baik adalah guru yang mampu membuat perencanaan pembelajaran, sehingga tentu akan mampu membuat strategi pembelajaran yang baik untuk memastikan bahwa pemilihan metode, ketersediaan media, dan peserta didik dapat saling bersinergi untuk menciptakan pembelajaran yang bermakna.

Untuk mengembangkan dan menyusun rencana pelaksanaan pembelajaran guru harus mencantumkan Kompetensi Inti yang memayungi Kompetensi Dasar yang akan disusun dalam rencana pelaksanaan pembelajaran. Di dalam rencana pelaksanaan pembelajaran secara 
rinci harus dimuat tujuan pembelajaran, materi pembelajaran, metode pembelajaran, langkah-langkah kegiatan pembelajaran, sumber belajar, dan penilaian.

Namun pada kenyataannya terdapat kesulitan dalam menyusun perangkat perencanaan pembelajaran yakni rencana pelaksanaan pembelajaran. Kendala tersebut menjadi satu masalah yang seringkali dihadapi dalam kehidupan pembelajaran para guru. Banyaknya kendala dalam penyusunan ini menyebabkan guru menjadi kurang maksimal dalam proses pembelajaran di dalam kelas. sehingga banyak guru yang hanya copy paste dari RPP sebelumnya. Padahal sebagaimana yang kita ketahui bahwa seorang guru itu diharuskan dan diwajibkan untuk menyusun rencana pelaksanaan pembelajaran sesuai dengan amanat undang-undang.

Akan tetapi berbeda hal dengan kondisi guru di SMP Pewaris Peradaban. Masih banyak guru yang belum mampu menyusun perangkat Pembelajaran yakni Rencana Pelaksanaan Pembelajaran (RPP), Prota dan Prosem dengan baik bukan karena para guru malas untuk membuatnya akan tetapi beberapa guru ada yang bukan lulusan sarjana pendidikan dan beberapa masih dalam proses kuliah. Oleh karena itu perlu diberikan suatu pemahaman kepada para dewan guru terkait pengembangan perencanaan pembelajaran pada sekolah tersebut guna meningkatkan pemahaman dalam mengembangkan perangkat pembelajaran khususnya rencana pelaksanaan pembelajaran (RPP).

Seperti yang telah dilakukan pada penelitian sebelumnya tentang Pelatihan Penyusunan Perangkat Pembelajaran K13 Di SDN Sudimoro 2 Kecamatan Bululawang Kabupaten Malang bahwa hasil penelitian menunjukkan adanya peningkatan pemahaman penyusunan perangkat perencanaan pembelajaran dari 80,2 \% menjadi 91,6 \% (Crhisyawani dan Werdiningtyas, 2018:1). Maka diharapkan dengan diberikannya pelatihan pada guru SMP Plus Pewaris Pearadaban dapat membantu meningkatkan pemahaman dalam menyusun perangkat pembelajaran khususnya dalam mengembangkan slabus dan menyusun RPP.

Selain tujuan diatas maka pengabdian kepada masyarakat dilakukan oleh dosen, mahasiswa, Prodi PPKn Unpam bertujuan untuk: Meningkatkan rasa kepedulian kepada masyarakat dan meningkatkan kepekaan sosial terhadap permasalahan yang dihadapi masyarakat dan berusaha memberikan solusi terbaik sehingga dengan dasar keilmuan yang dimiliki dapat bermanfaat bagi masyarakat. Adapun tujuan eksternal Pengabdian kepada masyarakat bagi 
masyarakat bertujuan sebagai berikut: Kegiatan lebih rinci tertuang dalam tabel di pertama, memberikan pemahaman kepada bawah ini:

para guru tentang pentingnya mengembangkan silabus dan rencana pelaksanaan pembelajaran. Kedua, memberikan pelatihan kepada para guru tentang teknis mengembangkan silabus dan rencana pelaksanaan pembelajaran. Ketiga, memberikan contoh nyata kepada para guru akan manfaat dari penyusunan silabus dan rencana pelaksanaan pembelajaran.

\section{METODE}

Tempat pelaksanaan pengabdian masyarakat dilaksanakan di SMP Plus Pewaris Peradaban Kecamatan Ciseeng Kabupaten Bogor. Waktu pelaksanaannya pada hari Rabu s/d Jum'at tanggal 12 s/d 14 Desember 2018. Target sasaran pengabdian ini yaitu guru SMP Plus Pewaris Peradaban berjumlah 12 orang. Prosedur yang dilaksanakan pada pelatihan ini pertama dengan metode ceramah. Guru diberikan materi tentang konsep, strategi, implementasi kurikulum 2013 dan strategi penyusunan perangkat pembelajaran. Kedua praktik, guru diberikan langkah-langkah penyusunan perangkat pembelajaran secara langsung. Ketiga penugasan guru diberikan penugasan untuk menyusun perangkat pembelajaran khususnya mengembangkan silabus dan Rencana Pelaksanaan Pembelajaran.

\begin{tabular}{|c|c|c|}
\hline Program & Metode & Partisipasi \\
\hline $\begin{array}{l}\text { Pelatihan } \\
\text { penyusunan } \\
\text { perangkat } \\
\text { perencanaan } \\
\text { pembelajaran }\end{array}$ & $\begin{array}{l}\text { Ceramah, } \\
\text { Tanya } \\
\text { jawab }\end{array}$ & $\begin{array}{l}\text { Peserta } \\
\text { mendengarkan } \\
\text { materi konsep } \\
\text { dan strategi } \\
\text { implementasi } \\
\text { kurikulum } \\
2013 \\
\text { kemudian } \\
\text { dilakukan } \\
\text { Tanya jawab } \\
\text { atas materi } \\
\text { yang sudah } \\
\text { dipaparkan } \\
\text { oleh pemateri }\end{array}$ \\
\hline $\begin{array}{l}\text { Pelatihan } \\
\text { penyusunan } \\
\text { perangkat } \\
\text { perencanaan } \\
\text { pembelajaran }\end{array}$ & Praktik & $\begin{array}{l}\text { Peserta } \\
\text { pelatihan } \\
\text { melihat secara } \\
\text { langsung } \\
\text { praktik } \\
\text { penyusunan } \\
\text { perangkat } \\
\text { perencanaan } \\
\text { pembelajaran. }\end{array}$ \\
\hline & Penugasan & $\begin{array}{l}\text { Peserta } \\
\text { pelatihan }\end{array}$ \\
\hline
\end{tabular}




\begin{tabular}{|l|l|l|}
\hline & diberikan \\
& penugasan \\
untuk \\
menyusun \\
perangkat \\
perencanaan \\
pembelajaran \\
(silabus dan \\
Rencana \\
\\
\end{tabular}

Ganbar 1

Metode kegiatan pelatihan

\section{HASIL DAN PEMBAHASAN}

Kegiatan pengabdian kepada masyarakat yang berbentuk pelatihan guru pada SMP Plus Pewaris Peradaban berjalan lancar dari tahap perencanaan sampai pada tahap evaluasi. Pada tahap perencanaan dilakukan beberapa tahapan. Pertama, tim melakukan observasi ke sekolah untuk mencari permasalahan yang muncul dalam implemetasi kurikulum 2013. Setelah mendapatkan permasalahan yang didapatkan dari hasil wawancara dengan guru bahwa "belum sepenuhnya guru memahami penyususunan perangkat perencanaan pembelajaran kurikulum 2013" maka hasil dari observasi kemudian ditetapkan oleh tim untuk melakukan pengabdian kepada masyarakat dalam bentuk pelatihan penyusunan perangkat perencanaan pembelajaran. Langkah kedua menetapkan sekolah tempat pengabdian masyarakat. Dalam langkah ini dilakukan pembentukan Tim dosen untuk melakukan pengabdian masyarakat, perencanaan waktu dan tempat pengabdian dan mengurusi izin pengabdian baik kepada Universitas Pamulang maupun perizinan ketempat pengabdian. Terakhir dalam tahap perencanaan ini dilakukan penyiapan materi pelatihan oleh tim pengabdian.

Adapun rincian pelaksanaan digambarkan dalam tabel berikut ini : 
3. Permendikbud No. 24 tahun 2016 tentang KI dan KD Pelajaran pada Kurikulum 2013

4. Peraturan pemerintah No. 19 Tahun 2017 tentang perubahan PP No. 74 tahun 2008 tentang guru

5. Teknik pengembangan silabus

6. Teknik penyusunan Rencana Pelaksanaan Pembelajaran

- Diskusi tentang permasalahan yang dihadapi guru dalam menyusun perangkat perencanaan pembelajaran

- Penugasan kepada guru untuk menyusun perangkat perencanaan pembelajaran

Tahap Evaluasi:

- Mengevaluasi sejauh mana tingkat pemahaman guru

\section{Gambar 2}

\section{Alur Pelaksanaan Pengabdian}

Dalam pelaksanaan Kegiatan pelatihan penyusunan perangkat perencanaan pembelajaran diikuti oleh seluruh guru SMP Plus Pewaris Peradaban berjumlah 12 orang dengan penuh antusias dan keinginan menambah pemahaman guru tersebut. Mereka merasa senang mengikuti pelatihan tersebut karena sebagian besar guru tersebut sebelumya belum mengikuti pelatihan secara penuh dan sebagian masih belum sepenuhnya memahami dalam mengembagkan perangkat pembelajaran dikarenakan beberapa guru bukan lulusan sarjana pendidikan. Maka dari itu hasil wawancara sebelum pelatihan sekitar $50 \%$ guru yang sudah memahami penyusunan perangkat pembelajaran.

Pelatihan tersebut dilaksanakan selama 3 hari dan melalui beberapa tahapan. Tahap pertama dengan metode ceramah. Dewan guru diberikan materi tentang konsep, strategi, implementasi kurikulum 2013 oleh pemateri pertama yakni Drs. Alinurdin.,M.Pd. Materi dijabarkan mulai dari penyampaian Permendikbud No.20 tahun 2016 tentang Standar Kompetensi Lulusan, Permendikbud No. 24 tahun 2016 tentang KI dan KD Pelajaran pada Kurikulum 2013 serta pengembangan Indikator Pencapaian Kompetensi (IPK). Materi tersebut dikemas dan disampaikan dengan rinci agar bisa diterima dengan baik oleh peserta.

Selain metode ceramah terjadi sesi tanya jawab dan diskusi antara pemateri dengan peserta pengabdian yakni dewan guru. Para dewan guru antusias menanyakan hal-hal yang berkaitan dengan kurikulum 2013 revisi terbaru dan menambah wawasan mereka tentang implementasi kurikulum 2013 yang sesunguhnya. Karena sebagian guru belum pernah mengikuti pelatihan kurikulum 2013 maka materi yang 
disampaikan benar-benar memberikan pemahaman bagi dewan guru dalam mengimplementasikan kurikulum 2013 khususnya untuk menyusun perangkat pembelajaran .

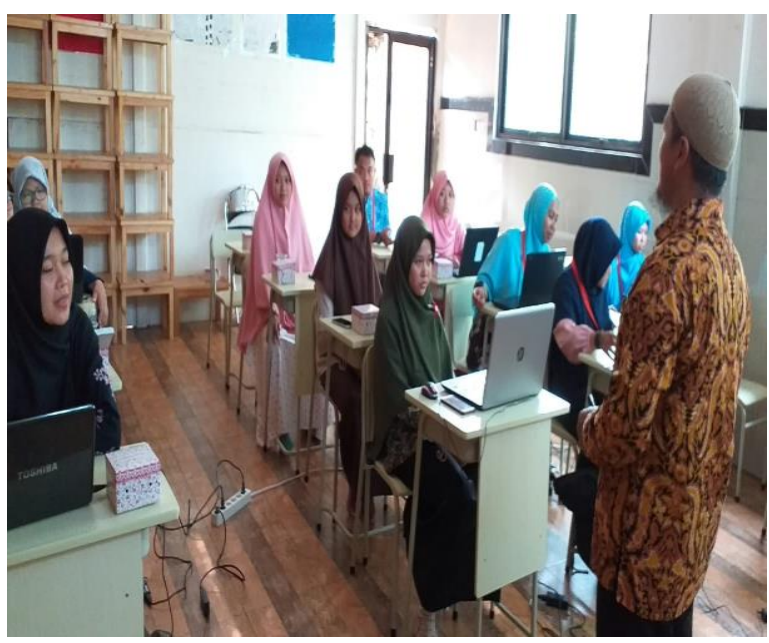

Gambar 3

Pelaksanaan kegiatan pelatihan

Selanjutnya peserta masih diberikan materi pengembangan silabus kurikulum 2013 revisi 2017 oleh Suanto.,S.Pd.,MH. Pada tahap ini para guru tidak hanya diberikan materi akan tetapi peserta diberikan contoh langsung dalam mengembangkan silabus terbaru. Karena pada kurikulum 2013 revisi terbaru, dinas tidak memberikan silabus secara utuh melainkan hanya memberikan $\mathrm{KI}, \mathrm{KD}$, serta pembelajaran saja maka guru perlu mengembangkan indikator, jumlah jam serta sumber pembelajaran yang ada dalam format silabus. Sesuai dengan permendikbud No.61 Tahun 2014 tentang Kurikulum Tingkat Satuan pendidikan.

Setelah memberikan contoh langsung maka guru diberikan penugasan untuk mengembagkan silabus sesuai mata pelajaran yang diampu. Selama penugasan maka tim pengabdi masing-masing mobile untuk mengecek keberlangsungan penugasan dan memberikan arahan dan jawaban jika ada yang mengalami kesulitan.

Temuan yang didapatkan dari hasil observasi saat pelatihan terdapat peningkatan pemahaman dalam mengembangkan silabus. sebelumnya hanya sekitar 6 dari 12 guru yang faham dalam mengembangkan silabus dan meningkat menjadi 10 dari 12 guru dapat dengan baik mengembangkan silabus dari masing-masing mata pelajaran yang diampunya.

Sesi selanjutnya peserta diberikan materi pengembangan rencana pelaksanaan pembelajaran yang disampaikan oleh Aulia Nursyifa.,S.Pd.,M.Pd secara teoritis dan Sulastri.,S.Pd.,MH menyampaikan secara teknis penyusunan rencana pelaksanaan pembelajaran. Dalam proses penyampaian materi terjadi tanya jawab antar pemateri dan peserta. Setelah semua materi disampaikan maka tahap selanjutnya para guru diberikan penugasan untuk mengembangkan Rencana Pelaksanaan Pembelajaran (RPP) sesuai mata pelajaran yang diampu. Mulai dari menentukan $\mathrm{KD}$, mengembangkan indikator dari KD, merumuskan langkah 
pembelajaran sampai pada penilaian. Semua guru antusias dalam melaksanakan tugasnya. Saat guru mengerjakan tugas maka tim pengabdi mendampingi untuk memberikan arahan jika ada suatu hal kendala atau hal yang belum dipahami dari guru. Kegiatan berjalan kondusif dan tenang. Guru dibimbing sampai menyelesaikan minimal satu KD dari mata pelajaran yang diambil sehingga tersusun RPP yang sesuai.

Setelah kurang lebih 2 jam maka sesi akhir pun selesai dan guru berhasil mengerjakan tugasnya dengan baik. Semua peserta mengumpulkan hasil tugasnya dan ditindak lanjuti oleh tim pengabdi untuk diberikan penilaian apakah terjadi peningkatan pemahaman terhadap Silabus dan RPP yang telah disusun.

Dari hasil analisa produk yang dibuat oleh masing-masing guru maka terjadi peningkatan pemahaman dalam

mengembangkan perangkat perencanaan pembelajaran dari $50 \%$ meningkat menjadi 91,6 \% yang awalnya hanya 6 dari 12 guru yang cukup memahami kemudian setelah mengikuti pelatihan meningkat 10 dari 12 guru yang hadir dapat dengan baik menyusun perangkat perencanaan pembelajaran.

Berdasarkan penjelasan materi dan penugasan dalam menyusun perangkat pembelajaran, guru mampu menyusun perangkat perencanaan pembelajaran dengan baik. Sesuai dengan pendapat Gagne dan Briggs (dalam Masjid, 2007:96) bahwa rencana pembelajaran yang baik itu hendaknya mengandung tiga komponen yang disebut Anchor poin, yakni tujuan pengajaran,materi pelajaran atau bahan ajar, pendekatan dan metode mengajar, media pengajaran dan pengalaman belajar, serta evaluasi keberhasilan.

Hal ini juga sesuai dengan pendapat Kenneth D. Moore (dalam Masjid, 2007:96) bahwa "komposisi format rencana pembelajaran meliputi komponen: a) topik bahasan, b) tujuan pembelajaran (kompetensi dan indicator kompetensi), c) materi pelajaran, d) kegiatan pembelajaran, e) alat atau media yang dibutuhkan, dan, f) evaluasi hasil belajar". Sehingga Rencana Pelaksanaan Pembelajaran yang disusun berdasarkan kurikulum terbaru yakni kurikulum 2013. Selain itu juga memuat pengembangan karakter dan pertanyaan yang dibuat sudah menggunakan HOTS.

Implikasi kegiatan pelatihan ini yakni adanya jalinan kerjasama antara kedua belah pihak. Jadi setelah kegiatan pelatihan ini tim dosen akan berusaha terus memberikan bimbingan kepada guru dalam bentuk merevieu perangkat pembelajaran yang dibuat oleh guru SMP Plus Pewaris Peradaban bahkan akan siap memberikan 
pelatihan kembali yang dibutuhkan guru SMP Plus Pewaris Peradaban.

Keunggulan pelatihan tersebut memberikan pemahaman guru dalam mengembangkan perangkat pembelajaran dan mengupgrade guru untuk selalu meningkatkan kualitas.

Adapun kekurangan pelatihan penyusunan perangkat pembelajaran yaitu persiapan harus lebih lama lagi sehingga pelaksanaan menjadi lebih baik lagi.

\section{KESIMPULAN}

Pengabdian kepada masyarakat dalam bentuk pelatihan yang berjudul "pelatihan penyusunan perencanaan perangkat pembelajaran" ini berjalan lancar sesuai dengan perencanaan awal sampai akhir kegiatan. Kelemahan dalam kegiatan pelatihan ini yakni sebagian guru belum memahami bagaimana dalam mengembangkan silabus dan Rencana Pelaksanaan Pembelajaran sehingga kegiatan pelatihan ini sangat sesuai dengan kebutuhan guru

Hasil dari pengabdian terlihat dari awal kegiatan pelatihan semua guru antusias dan semangat untuk mengikutinya sampai selesai. Ditambah dalam berjalannya kegiatan hampir semua guru aktif bertanya pada saat sesi tanya jawab. Selain itu juga kesan dari beberapa guru sangat senang mengikuti pelatihan tersebut dan menjadi lebih memahami dalam menyusun perangkat perencanaan pembelajaran. Hal ini juga terlihat pada peningkatan pemahaman guru sebesar 91,6 \%. 10 dari 12 guru yang hadir dapat dengan baik menyusun perangkat pembelajaran sesuai dengan kurikulum terbaru yakni kurikulum 2013. Yang awalnya hanya sekitar 6 guru dari 12 guru yang cukup paham dalam menyusun perencanaan pembelajaran.

Kegiatan pengabdian ini bermanfaat tidak hanya bagi Universitas Pamulang tetapi juga bagi guru SMP Plus Pewaris Peradaban.

Kegiatan pengabdian ini diharapkan dapat dilaksanakan secara berkelanjutan sehingga supaya guru bisa meningkatkan kualitasnya.

\section{UCAPAN TERIMAKASIH}

Terimakasih banyak untuk Yayasan Universitas Pamulang dan para dosen Prodi PPKn Universitas Pamulang yang telah memberikan dukungan materil dan moril, terimakasih pula untuk Yayasan Pewaris Peradaban yang telah mengizinkan dan menyiapkan tempat pelaksanaan pelatihan ini sehingga kegiatan ini berjalan dengan lancar.

\section{REFERENSI}

Crhisyawani, D Delawanti dan Werdiningtyas, R Kartika. (2018) Pelatihan Penyusunan Perangkat 
Pembelajaran K13 Di SDN

Sudimoro 2 Kecamatan Bululawang

Kabupaten MALANG. J Jurnal

Widya Laksana Vol.7 no

1.Universitas Kanjuruhung Malang.

Retrieved from

https:/ejournal.undiksha.ac.id/index

.php/JPKM/article/viewFile/12610/

8288

Indianti, Intan. (2014). Pelatihan Penyusunan

Perangkat Pembelajaran Bagi Guru MA se-Kota Semarang. Jurnal E.Dimas Universitas PGRI Semarang. Retrieved from https://www.neliti.com/publications/16 8614/pelatihan-penyusunan-perangkatpembeljaran-bagi-guru-ma-se-kotasemarang

Masjid, Abdul. (2007). Perencanaan Pembelajaran (Mengembangkan
Standar Kompetensi Guru).

Bandung: PT Remaja Rosdakarya.

Mulyasa, E. (2007). Kurikulum Tingkat Satuan Pendidikan. Bandung: PT Remaja Rosdakarya.

Mulyoto. 2013. Strategi Pembelajaran di Era Kurikulm 2013. Jakarta: Prestasi Pustaka Raya.

Permendikbud No. 65 Tahun 2013 tentang Standar Proses Pendidikan Dasar dan Menengah

Permendiknas. 2007. Tentang Standar Proses Untuk Satuan pendidikan Dasar dan menengah. Jakarta: BSNP.

Undang-undang Nomor 20 Tahun 2003 tentang Sistem Pendidikan Nasional. 